\title{
The effect of storms on Finnish dairy farms: electrical outage statistics and the effect on milk production
}

\author{
Hanna Huitu $^{1}$ (D) Kim Kaustell ${ }^{1}$ (D) Matti Pastell ${ }^{1}$ (D)
}

Received: 19 November 2018 / Accepted: 20 August 2020 / Published online: 1 September 2020

(c) The Author(s) 2020

\begin{abstract}
Due to technological advancement, agricultural production is increasingly dependent on electricity. At the same time, power delivery infrastructures are challenged by extreme weather events. Losses in primary food production due to electrical outages are still largely unquantified. This paper reports the effect of storm-induced power outages on milk production in Finland. The study used detailed, farm-level records of power cuts from 2010 to 2015 available from two power companies and contrasted them to the respective monthly milk production statistics collected at farm level. For each major storm event, deviation in the milk production compared to previous month was calculated for each farm. Effect of power outages onto milk production was estimated using linear mixed modeling. Power outages mainly occurred during and after storm events, and dairy farms experienced more outages than what was a national average for rural power customers. The power outages decreased the monthly milk yield of the most affected farms by $4.6 \%$ (farms experiencing outages longer than $72 \mathrm{~h}$ ), and production recovered already for the month following the storm event. The results imply that milk production in Finland is prepared and resilient toward power outages shorter than 3 days and that the current magnitude of power outages in dairy farms is higher than what was known previously.
\end{abstract}

Keywords Power outage $\cdot$ Dairy farming $\cdot$ Milk production $\cdot$ Storm

\section{Introduction}

Technological advancement has made agricultural production more and more dependent on electricity. At the same time, power delivery infrastructures are increasingly challenged by extreme weather events. Extreme weather events have been identified as a major cause of power failures worldwide (Campbell and Lowry 2012; Panteli and Mancarella 2015; Mukherjee et al. 2018). However, losses in primary food production due to electrical outages are still largely unquantified.

The Finnish milk production sector serves several important goals. Annual production of 2.3 million tonnes fulfills the high national demand-yearly per capita consumption of milk

Hanna Huitu

hanna.huitu@luke.fi

1 Natural Resources Institute Finland (Luke), Latokartanonkaari 9, 00790 Helsinki, Finland 
in Finland is over $120 \mathrm{~L}$, which is among the biggest highest in the world (FAO 2020). Dairy products are also the most significant single product group in Finnish food exports: They represent $17 \%$ of the total food exports (Finnish Customs 2019) and thus bring export revenue.

In a complex technological system like a modern dairy farm, energy consumption and share of electricity from the total energy use are dependent on the technology at the dairy farm (Upton et al. 2015). Electricity also plays a major role in powering control, automation, surveillance, and information management systems. Failure in one electricity-dependent part may cause collapse of another. Severity of the impact can vary by farm and by storm and also according to season and its respective outdoor temperatures. During severe storms, also other functions in the milk supply chain such as logistics or processing are likely to experience problems and thus final impact on milk production may be bigger than seen at the farm-based production volumes. Studies carried out in Canada showed that an ice storm in 1998 caused severe damage to electric power system (Chang et al. 2007) and approximately 5500 farmers were affected and 13.5 million liters of milk was discarded (Dupigny-Giroux 2000). Similarities may be found with other natural disasters: When studying effects of ash eruption on dairy farming, Wilson and Cole (2007) found electrical power supply to be one of the most critical and most vulnerable part of farm infrastructure that could be lost.

Modern dairy farms need constant provision of electricity to maintain milk production. For instance, in Finland, on-farm electricity use (including milking, milk cooling, washing of milking equipment, manure removing, air-conditioning, fodder processing and delivery, lighting) has been calculated to $0.7 \mathrm{MJ}$ per liter of milk, which accounts for $66 \%$ of the total energy use in conventional dairy farming and $55 \%$ of the total energy use in organic farming (Grönroos et al. 2006). Power outage does not only cause short-term economic harm to the farm, but failure to milk the cows may also cause both immediate and long-term harm to the animal's well-being. The effect of prolonged milking interval (PMI) on the animals' productivity and health depends on the length of interval. In Finnish dairy farms, cows are normally milked 2-3 times/day. In an experiment of Lakic et al. (2011), single long milking interval of $24 \mathrm{~h}$ leads to only minor losses in milk production (under $1 \mathrm{~kg} /$ milking); however, long milking intervals have been reported to trigger inflammatory reactions (reflected in increase in somatic cell count in milk) and compromising the well-being of cows (Stelwagen et al. 2008; Lakic et al. 2011, Kohler et al. 2016). Stelwagen et al. (2008) showed that milk production can be recovered back to normal level even after $32 \mathrm{~h}$ PMI. Longer intervals of 2-4 days have been shown to suppress production up to 4 days after PMI leading to clear losses in production (Dalley and Davis 2006). Nowadays, many Finnish farms mitigate the impact of sudden power loss by using alternative power sources such as power aggregates, together with proper overall preparation and planning (OSF 2017). The impact of storms to milk production in Finland has thus far not been studied.

The aim of this study was to assess the effect of power outages caused by storms on milk production and to quantify the amount of electrical outages in dairy farms in important milk production areas of Finland.

\section{Materials and methods}

\subsection{Data collection}

We acquired power delivery data from two power companies that operate on different milk production areas in Finland (Fig. 1). The dataset contained the starting and ending times of 
each power outage of a client dairy farm and location coordinates for the client. Measured electricity use was not included in the data due to privacy protection. Data on power outages were available for 1.1.2010-31.12.2015.

Duration of each power cut was calculated based on their start and ending times. If outage records in the data overlapped (power cut was recorded to begin before or at the time the earlier power cut record ended), outages were merged to reflect true outage time experienced at the farm. Outages were divided into categories according to their duration. For each month, we extracted the total duration of the power outage during the respective month. When start time and ending time of the outage were at different months, the end time of the power cut determined the month of occurrence.

We used the national milk quota register to assess milk production at the farm. This register contains monthly volumes of milk for human consumption, delivered from each farm to a dairy. We extracted data for the time period 1.1.2010-31.12.2015. Number of observations available per farm in this dataset ranged from 1 to 72 , where 72 meant that a farm produced milk each month during the 6-year time period. In order to make monthly values intercomparable, we normalized yield by dividing it by the number of days in each month.

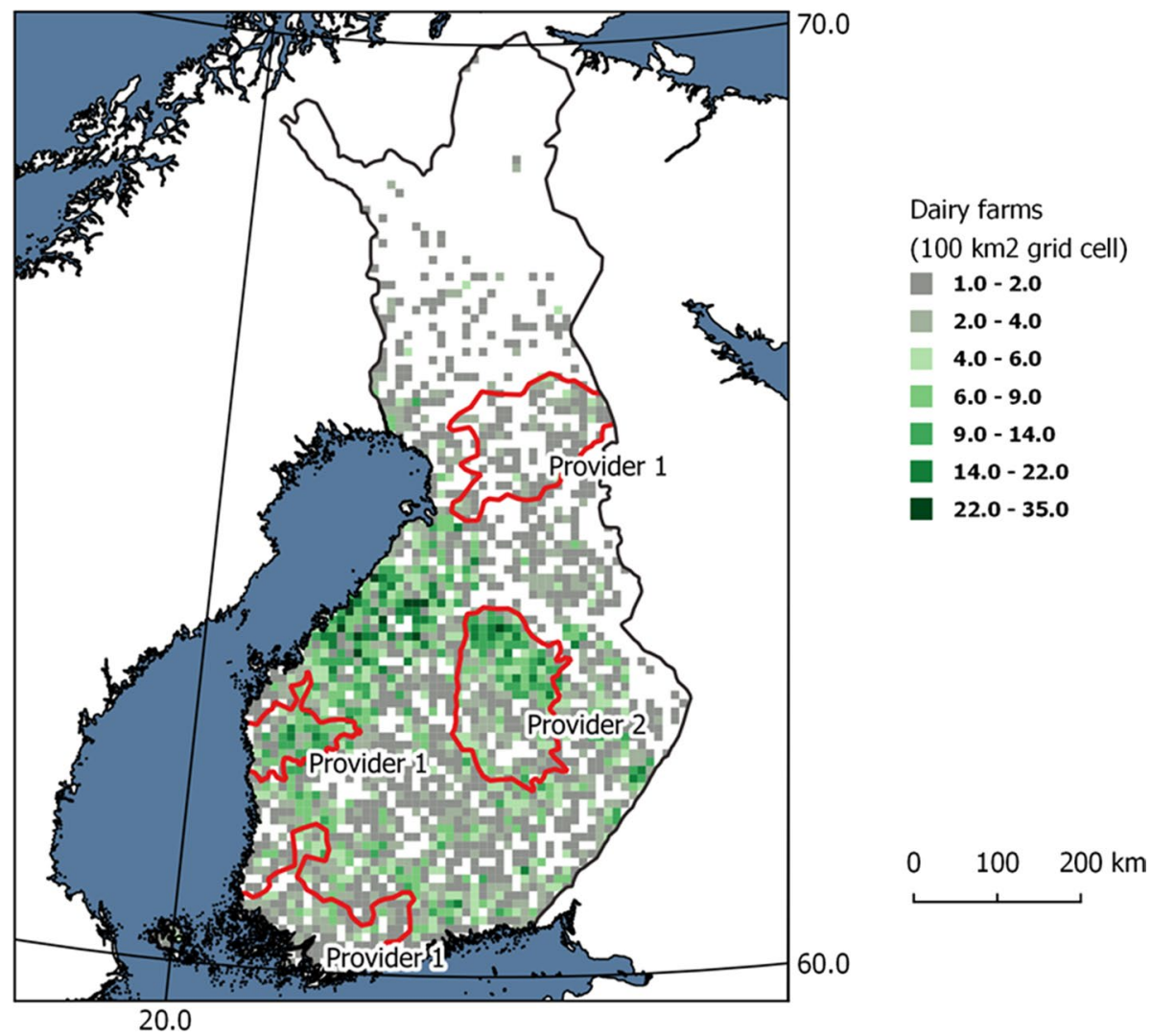

Fig. 1 A map showing density of dairy farms (number of dairy farms in $10 \mathrm{~km} * 10 \mathrm{~km}$ grid cells), based on the 2015 milk production register. The dataset covers all of Finland, so white color indicates complete absence of dairy farms in the respective $100 \mathrm{~km}^{2}$ grid cell. Location of the inspected areas lineated in red color, and the two power providers are labeled 
Map coordinates for each farm were linked to the dataset using farm registration numbers. Registration number is permanent over ordinary generational handover but changes to a new one when the farm is sold to non-family member. As a result of farmer cooperation, one location sometimes hosts cows from more than one registration number. We connected power cut information to the respective milk production records using map coordinates.

We identified seven major storm events during the study period (storm names in Table 1) that had caused power outages. As an indication of their severity, these storms felled more than 14 million cubic meters of trees in total and resulted in insurance compensations of more than 200 million euros (Gregow et al. 2016). We included only those storm events and areas where longer ( $>48 \mathrm{~h}$ ) power outages were experienced. For a storm occurring on the last day of the month (Storm "Asta" in Table 1), we expected the impact of the storm occurs on the following month. This is justified, as the production is measured only as the milk is collected from the farm, typically every 1-3 days.

January 2015 did not have actual storms in terms of heavy wind events, but as major power cuts were induced due to excessive snowfall, we included the month as one event in the study.

Two storm events from the area served by Provider 1 were excluded, as they did not contain records for power outages longer than $48 \mathrm{~h}$ for dairy farms (Table 1).

For each farm and each of the included storm events, we extracted normalized yield information for 3 months: the month that preceded the storm (Month 0), the month when the storm occurred (Month 1), and the month that followed the storm (Month 2). To exclude those farms that have just started at the time of the event or were very small (at least at the time of event) and thus likely to be unstable, we checked that (1) the production figures for the farm were available for the preceding 6 months and (2) production on Month 0 was larger than $5000 \mathrm{~L}$.

\subsection{Statistical analysis}

We used a linear mixed effects model to study the impact of long power outages to monthly recorded rates of milk production at a farm. We expected a decrease in the milk production on a farm that experiences a major power outage. This drop should be visible, when compared to the production on group of farms that during the same time did not experience major power outages.

The final model was a random intercept model of a form:

Table 1 Storm events analyzed in this study (labeling A-E as in Fig. 2)

\begin{tabular}{lllll}
\hline Date & $\begin{array}{l}\text { Storm name (if } \\
\text { any) }\end{array}$ & Storm event in the data & Provider 1 & Provider 2 \\
\hline 30.7.2010 & Asta & A $(8 / 2010)$ & Yes & Yes \\
4.8 .2010 & Veera & A $(8 / 2010)$ & Yes & Yes \\
7.8 .2010 & Lahja & A $(8 / 2010)$ & Yes & Yes \\
8.8 .2010 & Sylvi & A $(8 / 2010)$ & Yes & Yes \\
$26 .-28.12 .2010$ & Tapani & B $(12 / 2011)$ & Yes & Yes \\
17.11 .2013 & Eino & C $(11 / 2013)$ & No & Yes \\
$1 .-15.1 .2015$ & - & D $(1 / 2015)$ & Yes & Yes \\
$2 .-3.10 .2015$ & Valio & E $(10 / 2015)$ & No & Yes \\
\hline
\end{tabular}




$$
\Delta y_{i j}=\mu_{0}+\beta_{0}\left(\mathrm{OUT}_{i j} \times \operatorname{POSITION}_{i j}\right)+\mu_{j}+\epsilon_{i j}
$$

where $\Delta y_{i j}=$ change in monthly yield, $\mu_{0}=$ overall mean (fixed effect), $\beta_{0}\left(\right.$ OUT $_{i j} \times$ POSITION $\left._{i j}\right)=$ interaction between position and outage length, $\mu_{j}=$ storm mean (random effect), and $\epsilon_{i j}=$ random error.

The response variable $\Delta y_{i j}$ is formed using milk yield from the Month 0 as a baseline $\left(100 \cdot\left(y-y_{\text {Month } 0}\right) / y_{\text {Month } 0}\right)$. OUT is a discrete variable accepting values $(0,12,24,48$, or $72 \mathrm{~h}$ ) and shows the total duration of power outages on the farm during the storm month. The bin for value " 0 " contains all cases where outages lasted less than $12 \mathrm{~h}$, " 12 " all cases where outages lasted $12-24 \mathrm{~h}$, and so on, with " 72 " $\mathrm{h}$ containing all cases where total outage duration was greater than $72 \mathrm{~h}$. The POSITION variable categorizes the month either as one containing the storm (Month 1) or a month following the storm (Month 2). Identity of a storm event (A-E in Table 1; Fig. 2.) is categorical variable in the model and is treated as a random effect $\left(\mu_{j}\right)$ allowing the model intercept to vary per storm in order to account for change in average milk production between storms.

We checked the response and explanatory variables and did not find or remove outliers from the dataset. Collinearity was low among the explanatory variables. All explanatory variables were discrete. To validate the model, we checked the homogeneity and normality of the residuals and found no patterns.

All statistics were performed in $\mathrm{R}$ ( $\mathrm{R}$ Core Team 2016) using package lme4 (Bates et al. 2015).

(a)

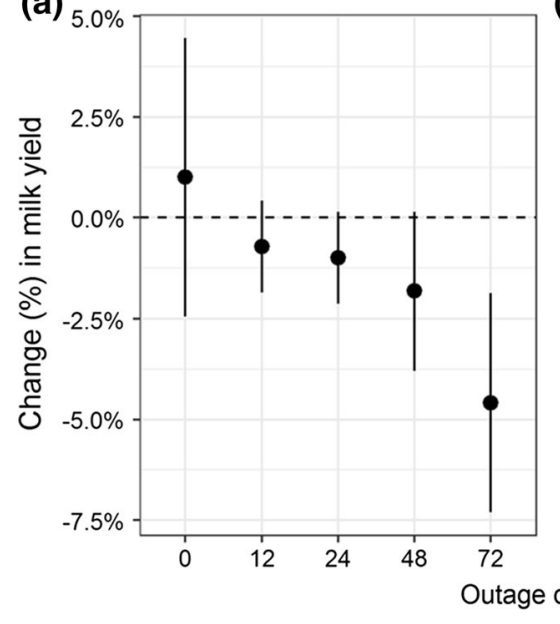

(b)

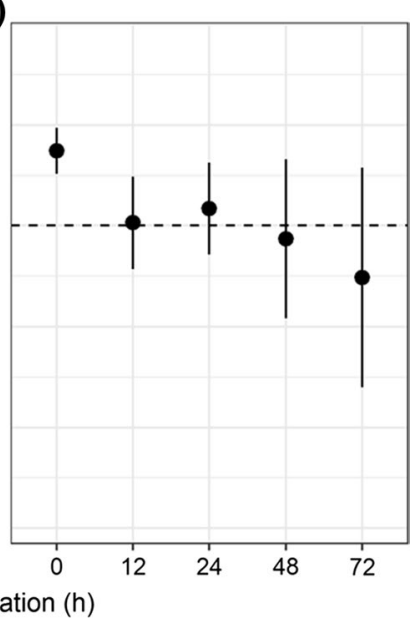

Fig. 2 Modelled change in monthly milk yield on a farm, calculated as a difference to the pre-storm level (yield for month preceding the storm). Farms are grouped according to the duration of the longest power outage, and outage duration in the figure is the lower bound in the range of the longest outages in the group. Black dots are estimates for change in milk yield, and attached vertical lines denote the $95 \%$ confidence level for the estimate. a Change in milk yield for the storm month; $\mathbf{b}$ change in milk yield for the month following the storm 


\section{Results}

\subsection{The effect of electrical outages on milk production}

In total, our dataset contained power cut and milk production records for 2563 dairy farms and 148,829 combinations of monthly production and power outage data, resulting an average 58 monthly observations per farm during the 6-year study period. Based on our analysis, dairy farms suffering power outages have decreased milk yield in Month 1, and duration of the outage affects the decrease. We found the decrease to be about $5 \%(4.59 \pm 2.72$ at $95 \%$ confidence level $)$ of the monthly production, when power outages had lasted for $72 \mathrm{~h}$ or more. Shorter power outages were associated with smaller decreases, not statistically differing from zero.

On Month 2, milk production had recovered on the affected farms and risen on notaffected farms for about $2 \%(1.86 \pm 0.57$ at $95 \%$ confidence level). Effects of power outages on milk production by outage duration categories are shown in Fig. 2.

\subsection{Occurrence of power outages at the farms}

Power outages on the farm were often associated with storm events. Figure 3 shows mean total monthly duration of power outages and the timing of storms identified in Table 1.

We found that the mean yearly total outage time per dairy farm was almost double the Finnish national average for rural inhabitants (Fig. 4). Farms that were operational only a part of a given year (for example, getting out of business or starting midyear) were excluded from the data of the given year.

During a 6-year period including years 2010 to 2015, most farms encountered at least one outage that was longer than $24 \mathrm{~h}$ and one to two outages longer than $12 \mathrm{~h}$. Outages lasting 72 h ( 3 days) or longer were rare. Figure 5 presents the distributions of the outages at individual dairy farms.

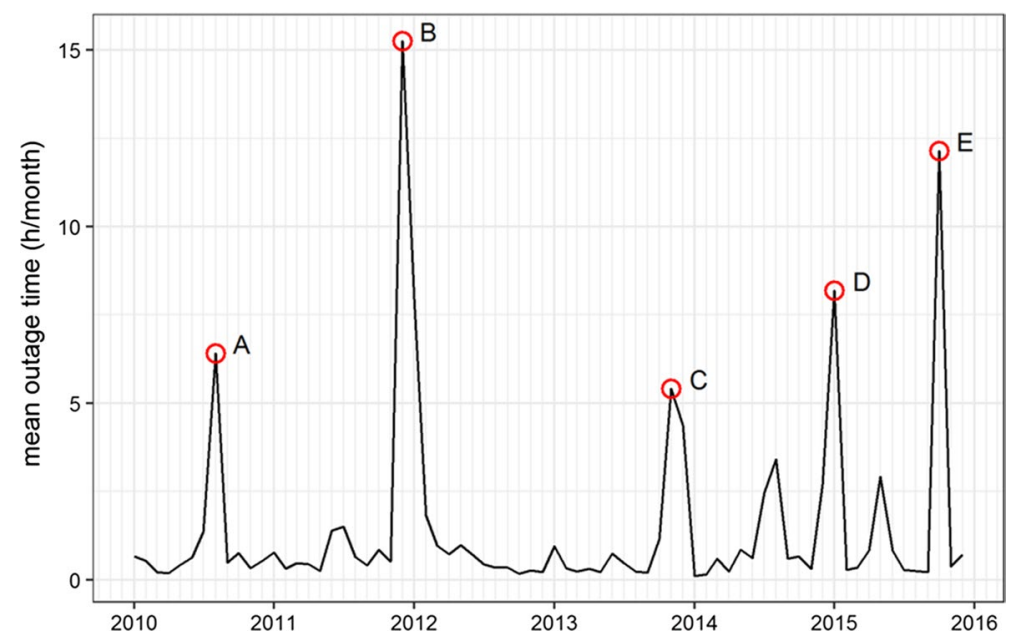

Fig. 3 Mean monthly duration of power cuts at a dairy farm. Labels (A-E) according to Table 1 


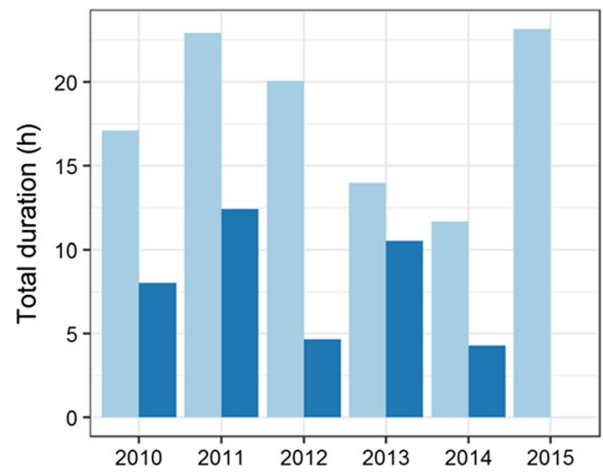

\section{Group}

a) Dairy farms studied

b) Rural areas, national average *)

Fig. 4 Mean yearly total duration (hours) of power outages per dairy farm (a). The values are calculated as an average for the operational farms in the dataset. Group b represents the mean yearly total duration Finland-wide for all power network customers in rural areas

\section{Discussion and conclusions}

We found that long power outages of at least $72 \mathrm{~h}$ caused $4.6 \%$ loss in monthly milk production. Shorter outages were not found to have a significant effect on farms milk production. The majority of power outages experienced by dairy farms were associated with major storms, and we quantified the mean outage time experienced.

We found that mean power outage time on a dairy farm was significantly longer than what has been earlier reported for an average rural customer. This may be connected to remote location of dairy farms outside villages. Remote areas are often more prone to

(a)

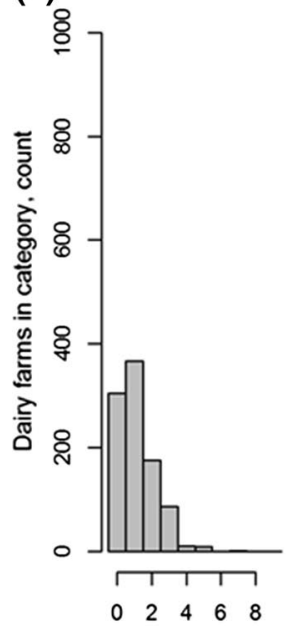

Outages $12-24 \mathrm{~h}$, count (b)

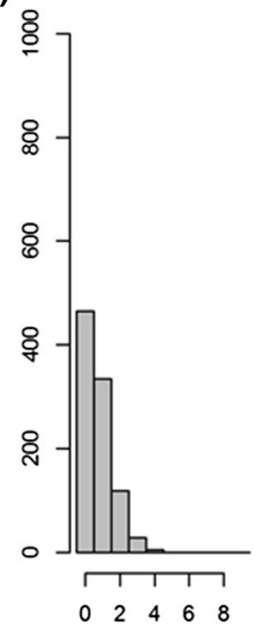

Outages $24-48 \mathrm{~h}$, count (c)

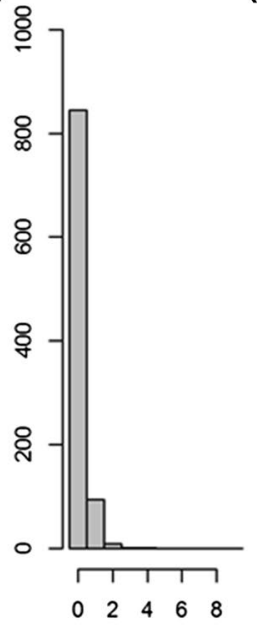

Outages $48-72 \mathrm{~h}$, count

(d)

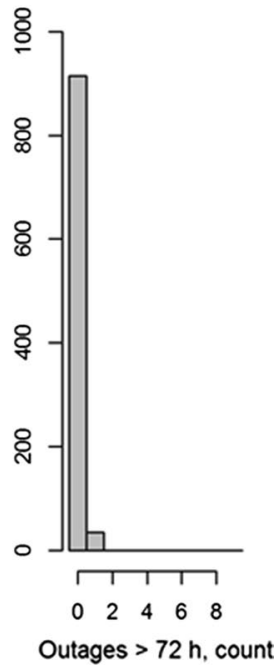

Fig. 5 Histograms showing the prevalence of long outages during the 6-year study period. Only dairy farms with a full 6-year production and power outage record $(n=950)$ are included. Graph a shows number of $>12 \mathrm{~h}$ power outages, graph $\mathbf{b}$ number of $>24 \mathrm{~h}$ outages, graph $\mathbf{c}$ number of $>48 \mathrm{~h}$ outages, and graph $\mathbf{d}$ number of $>72 \mathrm{~h}$ outages during the study 
power outages (Mukherjee et al. 2018). To the best of our knowledge, the dairy-farm specific burden from power outages has not been assessed before.

Production in the farm through the years varies for multiple reasons, some of which were included in the data. The milk production on farm is dependent on the number of milking cows and their yield as well as the lactation stage of the animals. The number of cows is subject to change via buying and selling of animals. These data at farm level were not available to us. Production numbers are thus affected by many factors, power outages being just one of them. In this study, we found that the impact of power cuts was strong enough to be visible despite the above-mentioned noise in the data. Estimated milk loss, however, was not large (4.6\%). Not-affected farms had an increase in milk production after the storm (production at Month 2 was $1.9 \%$ higher than at Month $0)$. It is possible that also farms affected by the storm would have experienced a corresponding rise without the storm, and thus, actual reduction in production on an affected farm could have been higher.

Wind damage on trees (trees falling on power line) is a major cause of longer-term power outages (Finnish Energy 2017; Krohns-Välimäki 2018). Under the common climate change scenarios, it is expected that tree susceptibility to storms will rise (Venäläinen et al. 2020 and references therein). At the same time, intensity of storms may increase (Gregow et al. 2017; Rädler et al. 2019). However, the reliability of the power network through the preparedness for storms is currently improved via new legal obligations to power companies and respective large investments (Nurmi et al. 2019).

Farms differ in their equipment and general preparedness, leading to different outcomes. According to a 2016 survey (OSF 2017), 74\% of the Finnish dairy farms had backup generators. A power generator enables milking at time of power outage, thus enabling milk production to market given that other necessary functions are sustained.

We found that our preselected storms indeed coincided with the peaks in power outage data, supporting the decision to limit analysis to those storm months. We were not able to control for the causes of individual power outages in the analysis, but since all occurred during a month of a major storm, we see that the connection between storm impact and the occurrence of power outages is safe to make.

Acknowledgements The authors would like to acknowledge the two power network companies (Caruna and Savon Voima) for contributing the data on power outages. The authors would also like to acknowledge the Finnish National Emergency Supply Agency and Ministry of Agriculture and Forestry of Finland for funding of this research.

Funding Open access funding provided by Natural Resources Institute Finland (LUKE). This study was funded by Finnish National Emergency Supply Agency and Ministry of Agriculture and Forestry of Finland.

\section{Compliance with ethical standards}

Conflict of interest The authors declare that they have no conflict of interest.

Open Access This article is licensed under a Creative Commons Attribution 4.0 International License, which permits use, sharing, adaptation, distribution and reproduction in any medium or format, as long as you give appropriate credit to the original author(s) and the source, provide a link to the Creative Commons licence, and indicate if changes were made. The images or other third party material in this article are included in the article's Creative Commons licence, unless indicated otherwise in a credit line to the material. If material is not included in the article's Creative Commons licence and your intended use is not permitted by statutory regulation or exceeds the permitted use, you will need to obtain permission directly from the copyright holder. To view a copy of this licence, visit http://creativecommons.org/licenses/by/4.0/. 


\section{References}

Bates D, Mächler M, Bolker BM, Walker SC (2015) Fitting linear mixed-effects models using lme4. J Stat Softw 67:1-48. https://doi.org/10.18637/jss.v067.i01

Campbell RJ, Lowry S (2012) Weather-related power outages and electric system resiliency. Congressional Research Service, Library of Congress, Washington

Chang SE, McDaniels TL, Mikawoz J, Peterson K (2007) Infrastructure failure interdependencies in extreme events: power outage consequences in the 1998 Ice Storm. Nat Hazards 41:337-358. https://doi. org/10.1007/s11069-006-9039-4

Dalley DE, Davis SR (2006) Effect of an extended milking interval on recovery of milk yield and somatic cell count in dairy cows. In: Proceedings-New Zealand society of animal production, vol 66, pp 241-244. (S2CID:86486606)

Dupigny-Giroux LA (2000) Impacts and consequences of the ice storm of 1998 for the North American northeast. Weather 55:7-15. https://doi.org/10.1002/j.1477-8696.2000.tb04012.x

FAO (2020) FAOSTAT Food Balance sheets (e-publication). http://www.fao.org/faostat/en/\#data/FBS. Accessed 19 July 2020

Finnish Customs (2019) International trade statistics (e-publication). https://tulli.fi/en/statistics\#. Accessed 19 July 2020

Finnish Energy (2017) Interruption statistics 2016 (Keskeytystilasto 2016, e-publication). https://energia.fi/files /1670/Sahkon_keskeytystilasto_2016.pdf. Accessed 19 July 2020

Gregow H, Carter T, Groundstroem F et al (2016) Measures to promote the management of weather and climate related risks (In Finnish, abstract in English). Publications of the Government's analysis, assessment and research activities 47/2016

Gregow H, Laaksonen A, Alper ME (2017) Increasing large scale windstorm damage in Western, Central and Northern European forests, 1951-2010. Sci Rep 7:46397. https://doi.org/10.1038/srep46397

Grönroos J, Seppälä J, Voutilainen P, Seuri P, Koikkalainen K (2006) Energy use in conventional and organic milk and rye bread production in Finland. Agr Ecosyst Environ 117:109-118. https://doi.org/10.1016/j. agee.2006.03.022

Kohler P, Alsaaod M, Dolf G, O'Brien R, Beer G, Steiner A (2016) A single prolonged milking interval of $24 \mathrm{~h}$ compromises the well-being and health of dairy Holstein cows. J Dairy Sci. https://doi.org/10.3168/ jds.2015-10839

Krohns-Välimäki H (2018) Development of a situation awareness system for disturbance management of electricity networks. Dissertation, Tampere University of Technology. http://urn.fi/. ISBN:978-952-15-4232-9

Lakic B, Svennersten Sjaunja K, Norell L, Dernfalk J, Östensson K (2011) The effect of a single prolonged milking interval on inflammatory parameters, milk composition and yield in dairy cows. Vet Immunol Immunopathol 140:110-118. https://doi.org/10.1016/j.vetimm.2010.11.022

Mukherjee S, Nateghi R, Hastak M (2018) A multi-hazard approach to assess severe weather-induced major power outage risks in the US. Reliab Eng Syst Saf 175:283-305. https://doi.org/10.1016/j.ress.2018.03.015

Nurmi V, Pilli-Sihvola K, Gregow H, Perrels A (2019) Overadaptation to climate change? The case of the 2013 finnish electricity market act. Econ Disasters Clim Change 3(2):161-190. https://doi.org/10.1007/s4188 5-018-0038-1

OSF Official Statistics of Finland (2017) Farm Structure Survey (e-publication). Helsinki: Natural Resources Institute Finland. https://stat.luke.fi/en/energy-consumption-agriculture-and-horticulture-2016-provisiona 1_en. Accessed 19 July 2020

Panteli M, Mancarella P (2015) Modeling and evaluating the resilience of critical electrical power infrastructure to extreme weather events. IEEE Syst J 11(3):1733-1742. https://doi.org/10.1016/j.epsr.2015.06.012

R Core Team (2016) R: a language and environment for statistical computing. R Foundation for Statistical Computing, Vienna

Rädler AT, Groenemeijer PH, Faust E, Sausen R, Púčik T (2019) Frequency of severe thunderstorms across Europe expected to increase in the 21st century due to rising instability. NPJ Clim Atmos Sci 2(1):1-5. https://doi.org/10.1038/s41612-019-0083-7

Stelwagen K, Farr VC, Nicholas GD et al (2008) Effect of milking interval on milk yield and quality and rate of recovery during subsequent frequent milking. Livest Sci 114:176-180. https://doi.org/10.1016/j.livsc i.2007.04.021

Upton J, Murphy M, De Boer IJM, Groot Koerkamp PWG, Berentsen PBM, Shalloo L (2015) Investment appraisal of technology innovations on dairy farm electricity consumption. J Dairy Sci 98:898-909. https ://doi.org/10.3168/jds.2014-8383

Venäläinen A, Lehtonen I, Laapas M, Ruosteenoja K, Tikkanen OP, Viiri H, Ikonen VP, Peltola H (2020) Climate change induces multiple risks to boreal forests and forestry in Finland: a literature review. Glob Change Biol 26(8):4178-4196. https://doi.org/10.1111/gcb.15183 
Wilson TM, Cole JW (2007) Potential impact of ash eruptions on dairy farms from a study of the effects on a farm in eastern Bay of Plenty, New Zealand; implications for hazard mitigation. Nat Hazards 43:103-128. https://doi.org/10.1007/s11069-007-9111-8

Publisher's Note Springer Nature remains neutral with regard to jurisdictional claims in published maps and institutional affiliations. 